\title{
TAARAPITA - THE GREAT GOD OF THE OESELIANS $^{1}$
}

\section{Urmas Sutrop}

We have read about Taarapita in the Chronicles of Henry of Livonia (Henrici Chronicon Livoniae), according to which he flew from the mountain where he was born (it is speculated that it was the Ebavere Hill in Northeast Estonia or Vaivara in the Blue Mountains) over to the Island Oesel. Local islanders screamed of joy over their Taarapita. Finally, when the whole country was Christianised, the inhabitants of Riga reportedly cast him out of the country and drowned him into the sea. It has also been speculated that the route of Taarapita's flight corresponds to the fall of the Kaali meteorite (Lõugas 1996, see also Viires 1990: 1420). The ancient Estonians must have perceived the meteorite as the god himself, who descended on earth with terrible destructive force and ear-splitting roar of thunder. The event definitely brought along changes in the contemporary worldview of the inhabitants of the area and in the more distant regions, and to be even more precise: it became a part of their worldview. Reverberations of this event have most likely been recorded in the Mediterranean region, or even Persia. The current study, however, will not aim to trace these reverberations. I will attempt to explicate the semantics and etymology of the name Taarapita, based on the works of Uku Masing (1939, 1995), on the elaborations by Lennart Meri (1976), on the overview by Ants Viires (1990), but also on the presentation of Aleksandr Kotljarevski in the Estonian Learned Society, held as early as in $1871 .^{2}$

In the following I will once again refer to the mentioning of Taarapita in the Chronicles of Livonia and will reconstruct the form as it appears in the chronicles. I will indicate that Taarapita is presently perceived in two ways: firstly, the misrepresentations concerning it (Taarapita as 'the owl god') and secondly, as a minor deity in the pantheon of Slavic gods. I will then observe the possible associations between Taarapita and other Slavic, Germanic, Celtic, Altaic and Ugric gods and will pose a question whether Taarapita may have been known in Estonia before the Chronicles of Henry. And 
finally I will analyse the word as a compound taara and pita, with a purpose to discover the possible meaning of the name Taarapita.

The name of the god, Taarapita, is important to us, the Estonians, which is why it has been a popular subject of study. Even so, we can probably be certain what Taarapita meant and symbolised in this country before the arrival of the Teutonic crusaders.

\section{TAARAPITA IN THE CHRONICLES OF HENRY OF LIVONIA}

Taarapita is mentioned five times in the Chronicles of Henry of Livonia. According to the general interpretation the name means a call for help Taara avita! 'Taara, help!' (see Viires 1990). This understanding is still held by the research group of the old Estonian literary language at the University of Tartu (Ehasalu et al 1997: 24 ). Such approach is commonly grounded on the fact that labials $p$ and $v$ may often be interchanged.

Lennart Meri argues: "Taarapita does not stand for hooting for help, but means "Taara's thunder". The ancient 'pitkne', or thunder was used as a taboo word but also signified both 'snake' and 'thunder" (Meri 1976: 107). Before I will begin confirming or refuting the argument, I intend to analyse the forms of the name, introduced by the Chronicles of Henry of Livonia, which have survived up to this day.

In the chronicles, Taarapita's name is mentioned since Chapter 24 (from the year 1220 to the end of the chronicles 1227). The original manuscript of the chronicles does not exist, or at least has not been found. The earliest and the most accurate transcript of the chronicle Codex Zamoscianus (Z) dates back to the early 14th century. Unfortunately, the transcript ends with division 8 of Chapter 23. Therefore, all five occurrences of the name Taarapita have been reconstructed on the basis of more recent and less accurate manuscript transcripts.

The extant manuscripts are generally divided into interpolated and uninterpolated manuscripts. All the extant manuscripts since Codex Zamoscianus are traceable to the hypothetical manuscript $\mathrm{X}$ 
from the late 14 th or early 15 th century. Manuscript X appears to be independent of manuscript Z (Figure 1). Further on sources and manuscripts, see Albert Bauer's introduction to the German editions of the chronicles (Arbusow \& Bauer 1955, 1959).

The Latin edition by Leonid Arbusow is based on manuscript Z, the blanks in manuscript Z and after Chapter 22/8, where Z ends, manuscripts $R$ and $S$, and manuscripts $T$ and o have also been consulted. The 2nd edition of Arbusow's edition includes comments on differences in the name form in different manuscripts of the chronicle (Arbusow \& Bauer 1955). Different name forms of Taarapita have been presented in Table 1.

Of all the name forms, the first one to stand out is Tharaphitam with an ending - $m$ "ut Christum predicent, ut Tharaphitam, qui deus fuit Osilianorum, eiciant" (220; “...in order to preach Christ and to throw out Tharaphita, the god of the Oeselians"; 244). ${ }^{3}$ Here, the scriber has simply added the Latin feminine accusative ending -am to the name (phita: phitam).

The form Therrapita, which appears once in manuscript $\mathrm{T}$, where $e$ - appears in the first syllable instead of an - $a-$, is an obvious scribal error, since everywhere else in the manuscript the name is spelt with $-a-$. The name forms of this manuscript could otherwise be characterised as having double consonants in the second syllable of both compound constituents (Tarrapitta). All the forms of manuscript T may therefore be discarded.

The next important issue is the occurrence of $-h$-, which appears in all the name forms (except for Tarrapitta (T), which we already have discarded), either in the first compound constituent or in the second, or in both. The lack of $-h$ - in the first part of the form Taarapita is apparently accidental. Therefore, the first compound constituent of the name in the chronicles is Thara. The second compound constituent has been subject to greater variation: pita, pitha, phita. Here it is virtually impossible to determine whether the grapheme $h$ has been of any semantic significance. Thus, we may take the form pita and use it in the compound Tharapita, as it first appeared in the chronicle text $(175,10)$. 


\section{Manuscript of Henry}

Archetypical manuscript from the $13^{\text {th }}$ century

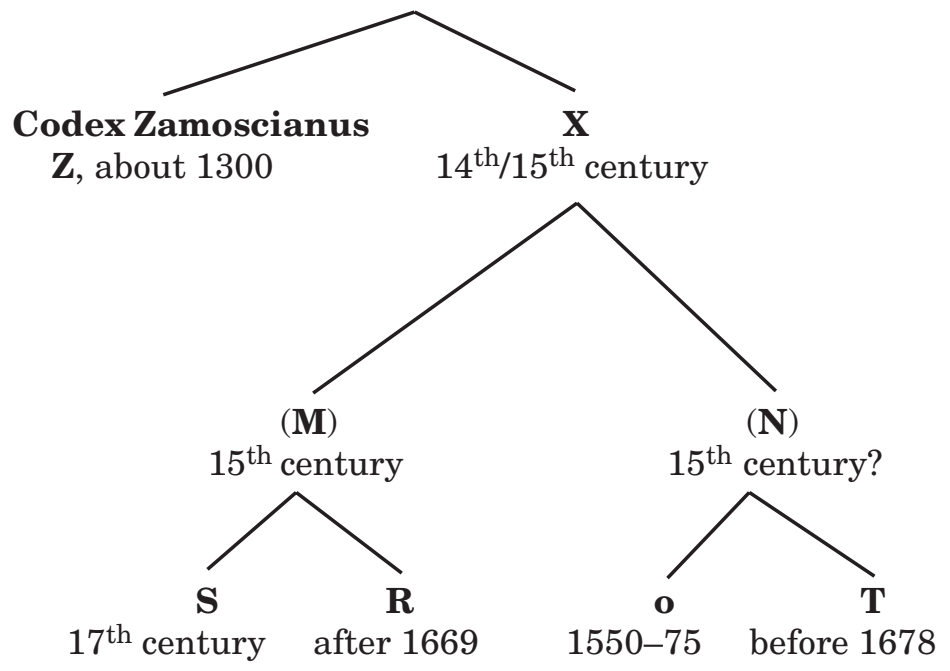

Figure 1. Manuscripts of the Chronicle of Henry of Livonia according to Arbusow and Bauer (1955, 1959). Later transcriptions of the chronicle have not been included. Uninterpolated manuscripts have been marked with upper case letters, interpolated with lower case letters. Hypothetical manuscripts with more recent transcriptions have been inserted into brackets $(X, M, N)$.

\begin{tabular}{|l|l|l|c|}
\hline Page, row & Text & \multicolumn{3}{|c|}{ Comments } \\
\cline { 3 - 5 } & & \multicolumn{1}{|c|}{ T } & o \\
\hline 175,10 & Tharapita & & \\
218,27 & Tarapitha & Therrapita \\
220,30 & Tharaphitam & Tarrapitta & Tarapitha \\
221,14 & Tharapitha & & \\
222,2 & Tharaphita & Tharrapitta & Tharapitha Tharaphita
\end{tabular}

Table 1. Name forms of Taarapita in different manuscripts of the Chronicle of Henry of Livonia according to the text and comments of Arbusow \& Bauer (1955). 
In this case the - $h$ - is meaningful only if we associated Thara with the Scandinavian god Pórr, i.e. if we accept that the loan route was from Scandinavia to Estonia. But even then the Estonian pronunciation would have been $t$ : taara-, not $t^{\mathbf{h}}$ : $t^{\text {h}}$ aara- (cf. also kuld, 'gold', Fin. kulta < Gothic gulp). Had $t$ : taara- been aspirated in any way, it would have been the great Scandinavian god, whose name was carefully imitated, rather than the great god of the Oeselians. But the chronicles referred to the great god of the people of island Oesel: ubi erat mons et silva pulcerrima, in qua dicebant indigene magnum deum Osiliensium natum, qui Tharapita vocatur, et de illo loco in Osiliam volasse (175; There was there a mountain and a most lovely forest in which, the natives say, the great god of the Oeselians, called Tharapita, was born, and from which he flew to Oesel; 193194).

Proceeding from the above argumentation I will hereinafter use the name form Taarapita (although the form Tharapita is also possible). In the Estonian-German dictionary by F. J. Wiedemann the keywords are tar, genitive tara 'eine mythologische Person, Geist', Tor, genitive Toru (Toro in South Estonia) 'Name einer Gottheit' and Torapitta, genitive Torapitta 'Name einer Gottheit'.

This allows us to analyse the name Taarapita, and Lennart Meri's interpretation of it as 'Taara's thunder'.

1) Thara-is a nominative form of the name. Apocope (omission of the word ending) has not yet occurred in the Estonian language. Thus, in the early $13^{\text {th }}$ century the nominative form was Taara, rather than *Taar (*tar). In this case we would have coordinating conjunction Taara+pita, and could still speculate that Taara derives from the Scandinavian Thor and the unknown has been explained through the known. Hence we could argue that Taarapita stands for "Thor of Thunder".

2) Thara- is a genitive form of the name. Paul Johansen, in his analysis of the compound toponyms in Liber Census Daniae, has argued that by the early 13 th century, the $n$-genitive had already disappeared from the Estonian Language (Johansen 1933: 293). Thus, the interpretation "Taara's thunder" is possible only if there is genitive compounding in the name Taarapita. This hypothesis is refuted by Alo Raun and Andrus Saareste, who argue that the $n$-end- 
ing that was not an inflectional morpheme began to fade only after the $15^{\text {th }}$ century. The genitive - $n$-ending began to fade and disappeared completely by in the following 16 th century (Saareste \& Raun 1956: $61 \mathrm{f}$.).

In the secure position - inside the compound - the genitive - $n$-ending may have been retained even longer (e.g. it is still present in modern Estonian word maa-n-tee 'earth's or land's way, road'). If the genitive - $n$-ending was not lost at this time, then the word must have appeared in the Chronicles of Livonia as *Tharanpita. Thus, we cannot state with certainty that Taarapita's semantic rendition is Taara's thunder.

Taara's thunder is a phrase similar to God's flash of lightning. But since God's flash of lightning cannot be the name of the god, lightning indicating to just one attribute of the god, Taara's thunder cannot be a god's name either, for thunder can be used in this expression only as an attribute of the god (Taara).

The only way to accept the thunder hypothesis is if we regard the coordinate compound as listing Taara, Pikne, meaning "Taara, Thunder". As I already mentioned, this would automatically identify Taara as Pórr, followed by a translation of the name for clarification. The full translation of Taarapita would, in this case, be "Thunder, Thunder". This, however, is not very plausible, since Taarapita would not be called the great god of the Oeselians, but the great Scandinavian god.

\section{OWL GOD AND THE SACRED HAZEL GROVE}

Martti Haavio has rightly demonstrated that Taarapita does not mean a battle cry Taara avita!, or "Taara, help!" (Haavio 1970). At the same time he tendentiously attempts to prove that neither the Estonians nor the inhabitants of Oesel had a god of their own. He relies on the following passage of the Chronicles of Henry: Gaudet exercitus christianorum, exclamant, Deum exorant. Clamant et illi, gaudentes in Tarapitha suo. Illi nemus, isti Jesum invocant... (218; The Christian army rejoiced, shouted, and implored God. The enemy also cried out, rejoicing in their Tharapita. They called upon their sacred grove, the Christians upon Jesus; 241-242). In his quo- 
tation of the passage, Haavio deviates from the original twice: firstly, there is a minor difference in hi (instead of the original isti) Jesum invocant; secondly, he uses the name form Taraphita, which does not appear in any of the chronicles manuscripts (see Table 1). In the quoted passage Haavio equates the name form Taraphita and the Latin nemus, meaning 'sacred grove', and suggests that Taarapita should be read as Tarap-hita, or 'hazel grove' (Livonian tarà B, or 'hazel' + *hitta (*hitto, hitte, hiisi-) 'sacred grove, Latin nemus'). Thus, "they" (the Estonians) rejoiced over their hazel grove, which reportedly was a sacred place; and afterwards called the same grove for help (Haavio 1970). Such interpretation, as well as the following bird god rendition, should be regarded as misinterpretations.

Contemporary research perceives Taarapita as an owl god, whose name was reportedly Tarapila (Tharapila). The recent extensive handbook on deities, for example, includes a short article in the section of zoomorphic and ornithomorphic gods entitled Tarapila: An Estonian owl god (Leach 1992: 267). The author and editors of the handbook should not be blamed for this absurdity, since the interpretation dates back to the first half of the last century. I would like to quote a passage from the supplement to Jacob Grimm's Teutonic mythology (Grimm 1965: III, 35):

The Finnic 'Tharapita' should be Tharapila (Klemm 3, 121). Castrén (215) thinks - pila is bild ['picture, figure'], but Renvall says Tharapilla $=$ horned owl, Estonian torropil ['bagpipe'], (verhandl. 2, 92). Juslen has pöllö bubo ['owl'] (284), and tarhapöllö bubo ['owl'] (373). ${ }^{4}$

Etymologically, this rendition is utterly ungrounded. Mart Mäger writes: "Popularly, all the birds belonging to the order of Strigiformes are called owls... The word tarapöll (<tarhapöllö) was a Finnish loan, which cognate in Estonian is päll, or 'owl', a name which is now obsolete" (1994: 199; cf. also Mäger 1967: 98). Thus, in the Estonian language, owls were formerly not known by the name tarapöll. According to Mart Mäger the Estonians sometimes distinguish between typical owls (family Strigidae) and northern eagle owls, or owls with "ears", or tufts of feathers on their heads. The Latin name for the northern eagle owl is Bubo bubo. The Finnic tarha 'fence', Estonian cognate tara, is a Baltic loan (tara $<$ tarha $<$ 
*tarša < Balt.: Lithuanian dar̃̌̌as). Such interpretation would suggest the Baltic origin of the name Taara, which, again, is incorrect.

The ornithomorphic god interpretation may rely on Adam of Bremen, who writes that the inhabitants of the island of Aestland (Ästland, Estland) worship dragons and birds, to which they make sacrifice humans, who are bought from merchants and carefully examined, so that they would not have physical deformities, so that the dragons would not reject them (Adam of Bremen 1986: 267 and 1987: 327). ${ }^{5}$ Even Taarapita is known to have flown from the Mountain [Mount Ebavere or Vaivara] to the Oesel Island. In the mid19th century Jacob Grimm posed a question: Did Tharapita fly as a bird? (Grimm 1965: I, 62). The name form he used, Tharapita, was later considered a typing error, which should be "correctly" read as Tharapila (Grimm 1965: III, XIV). Ants Viires writes that the author of the interpretation of Taarapita as an ornithomorphic god is Johann Leonhard von Parrot, who suggested the idea in 1828 (Viires 1990: 1412). Parrot argued thatTharapilla is a great bird (1828: 312) and not a garden ape (Gruber), bagpipe (Arndt) or cry 'Thor, help!" (Kelch) (Parrot 1828: 298 ff.).

The English translation of Teutonic Mythology (Grimm 1883: II, 669 ) and the book Bird Gods (de Kay 1898: 172-173) have prompted and helped to spread the misinterpretation of an Estonian owl god Tarapila (Tharapila).

\section{TAARAPITA IN THE SLAVIC PANTHEON}

On March 11, 1870, Aleksandr Kotljarevski delivered a presentation entitled "Estonian God as a Guest on the Island of Rügen" on the 371st meeting of the Learned Estonian Society (Kotljarewski 1871: 36-39). His presentation included several important results and conclusions.

Kotljarevski indicated that Taarapita of the Chronicles of Henry of Livonia is identical with Turupid, a deity in the Knytlinga Saga. He concluded that the form Tharapitha is the correct form [*Tharapila is evidently not]. He is convinced that the name is the reverberation of the name and form of the Scandinavian Thôr (Wiederhall). According to Kotljarevski, the meaning of the full name should be 
interpreted as Tar-awitaja (Thor-helper), where Tharapitha is Thar 'Thor' + apitha $<$ awita $\sim$ abita. ${ }^{6}$

Uku Masing has already touched upon the issue in his article "On the Origin of Taara" (1939). Saxo Grammaticus mentions three Slav gods on the island of Rügen, whose statues were destroyed by the Danish in 1168 or 1169 (Waitz 1964). In the same context, Knytlinga Saga mentions the god Turupið instead of Porevit or Porenut (Jónsson 1964).

Turupið does not belong to the Slavic pantheon. Many scholars of Slav mythology have suppressed this fact. Another approach since Kotljarevski links Turupið with the "Finnic" Taarapita. (Then again, scholars of Finnic mythology have conveniently suppressed mentioning of Taarapita). I will presently not elaborate further on how Turupið may have ended up on Rügen, nor have I anything particular to add to the reasoning of Uku Masing.

A. Brückner writes: “auch ein finnischer Gott, Tarapita, ist hier als Turupit eingeschmuggelt” (1925: 521). A French religion history account states that "Turupit n'est très probablement que le dieu finnois Tarapita" (Clemen 1960: 401). Or, "Turupid, hinter dem man einen finn. Tarapita vermutete" (Reiter 1973: 192). Jaan Puhvel writes in his textbook of comparative mythology: "Turupit resembles the god Tarapita attested for the Estonian island of Osilia in the Livonian Chronicle of Henricus Lettus" (1987: 232). At the same time authors symptomatically find it sufficient to mention the similarity between Turupið and Taarapita, without making any effort to provide evidence or attempt to refute their possible sameness. Even Grimm compares Taarapita with Turupið in his footnote comment to the Teutonic Mythology (Grimm 1965: I, 62, comment 2).

The names of Slav deities include a characteristic theonymic suffix -vit (further on this see e.g. Leger 1896). In Knytlinga Saga the names Rinvit and Puruvit appear next to Turupið. Turupið is commonly written in the form Turupit (both Uku Masing and Lennart Meri). Turupit originates in the Latin translation of Knytlinga Saga, and was, and still is, more convenient to use in print. The Latin form is actually misleading, and I intend to address to the matter below. 
Let us assume now that suffixes -vit and -pita are identical. The shift $p \sim v$ is natural (like the assumed abita $\sim$ awita) and -vit $>*^{*}$-pit $>$ *-pita; the added - $a$ transforms the suffix into a vowel stem word like most of the Balto-Finnic words.

Until recently there was no satisfactory etymological explanation for the Slavic theonymic suffix -vit. V. N. Toporov was the first to provide it (Toporov 1989: 36). He analyses the names Zwantewit/h/ , Svantavit, Szuentevit, etc. as *Sveto \& *vitъ and notes that scholars have found the *vits constituent quite troublesome, and that it is usually defined as 'lord', 'master' with a reference to the Church

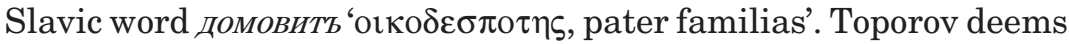
this rendition too generalising and provides the constituent *vits an Indo-European etymology.

According to Toporov *vits $<*$ * vikt , where $k$ and $t$ have assimilated and *viktъ, in its turn derives from an Indo-European variants *ueik$t$ or *uîk-t-from the root *ueik- denoting 'vitality, strong manifestation of strength', but also 'victim, dedication'. He gives an example of the Latin cognate victima 'sacrificial animal, reconciliation or thanksgiving sacrifice', which has also been derived from the root including the -t-element *vik-ti- or *vik-tu-. The etymological sequence of the Slavic theonymic constituent that we are interested in would be as follows: -vit $<*$ vits $<*$ vikts $<* v i k-t u-$.

In Modern Russian pronunciation there is no longer any difference between the pronunciation of -vit and * vits, but in the 12th century the Slavic $t$ sounded very dark before the reduced $u$ (b). Now we have come to the reason why the Latinised form Turupit is very misleading: this indicates that the $t$ in the suffixes -vit and -pit(a) are the same. Again, let us return to the divine triad on the island of Rügen in Knytlinga Saga - Rinvit, Turupið, and Puruvit. Evidently, the end suffixes of these names were perceived as different. The dark Slavic -viţ has been transformed into-vit, and-pit(a), as a completely different suffix, has been transformed into -pið.

Consequently, we may reject the assumption that the suffixes -vit and -pit(a) are identical, and agree with certainty that -pita is not of Slavic origin. Furthermore, the above said supports our argument that in the 12th century there indeed was a statue of the great god Taarapita - Turupið - on the island of Rügen. 
Leszek Moszynski has recently spoken about Celtic influences on the island of Rügen and has suggested that Turupit $<{ }^{*}$ Taran-vits may have been derived from the name of the Celtic thunder god Taranis (Moszynski 1992: 55). O. N. Trubacev, however, resolutely rules out Moszynski's interpretation of the name Turupit and Celtic influences on Rügen (Trubacev 1994a: 5, 1994b: 5-6).

\section{TAARA AND THE GERMANIC DONAR-PÓRR}

Uku Masing writes:

The name Taara became to signify the supreme deity of the Estonian people, but soon it began to fall. The name appeared everywhere, resulting in doubts whether it belonged anywhere, and although there was not doubt that the Estonians had once known a creature by that name, a question was posed whether such a deity is of Estonian origin, or is it a loan from the Scandinavian Thorr. The question has remained unanswered, and can, perhaps, be decided only when it has been established that the Scandinavian word has an Indo-Germanic etymology (1995: 47).

Firstly, I will observe how the Estonians or, in particular, the inhabitants of Oesel may have borrowed the Scandinavian name form, and secondly, I will demonstrate that the Scandinavian word does indeed have an Indo-European etymology.

\begin{tabular}{|l|l|l|}
\hline case & singular & plural \\
\hline Nominative & Pór-r & Pór-a-r \\
\hline Accusative & Pór- $\varnothing$ & Pór-a- $\varnothing$ \\
\hline Genitive & Pór-s & Pór- $\varnothing-a$ \\
\hline Dative & Pór-i & Pór- $\varnothing-u m$ \\
\hline
\end{tabular}

Table 2. Declension of the name Pórr (thematic a-root in plural, masculine) in Old Icelandic. Inflectional endings have been separated by hyphen, ø-mark indicates the lack of ending or stem vowel.

Table 2 shows that in singular the name always ends with a consonant. The use of a god's name in plural, where the accusative form ends with a thematic root vowel and the genitive form with an in- 
flectional ending - $a$, is highly unlikely. It is hardly possible to imagine the ancient Scandinavians addressing their god in plural. And it is even less likely that the use of plural would be passed on through language contacts. ${ }^{7}$ The only forms that could be borrowed were nominative or accusative, the object case. And, obviously, the name could have been borrowed only in consonant stem form.

Borrowing in vowel stem form would be thinkable, had the ancient Scandinavians used the word pórr appellatively as a gender name denoting 'god, gods'. Pórr may have had such appellative meaning only during the earliest stage of the Scandinavian god cult. The earlier name form of Pórr was Punarr, but the borrowing of Taara from this form would be unthinkable. Thus, if we regard Taara as a North-Germanic loan, it cannot be very old. Before I will discuss further whether Taara is a loan from the form Pór(-r), I will observe the occurrence of similar names among the Celts and in the Altaic and Ugric languages. But first - let us have a look at the Indo-European etymology of the name Pórr.

When Anglo-Saxons adopted the Roman calendar around 300 A.D., they called the fifth day Punresdæg after the Latin Jovis dies 'day of Jupiter', since the redheaded Germanic thunder god Pórr functionally corresponded to Jupiter, Zeus, Indra and other Indo-European thunder gods (Cotterell 1986: 187). The name of the weekday has been retained in nearly all Germanic languages to the present day: Swedish, Danish Torsdag, Old Scandinavian Pôrsdagr, British Thursday, Middle Low German dunredach, donerdach, Dutch donderdag, Old High German donarestag, Modern German Donnersdag. The Germanic pantheon is ruled by the common Germanic thunder god Donar, and Pórr in the northern regions. The names Donar-Pórr often appear in association (Beck 1986, Handwörterbuch 1929/1930: 307-345). Thus, Donar and Pórr can be considered functionally and semantically equal. But does this apply to their etymology?

Two-syllable names, such as the Anglo-Saxon Thunaer and the Old English Punor can be traced back to the form *DunaraR (nomen agentis from the verbal root), and the monosyllabic Nordic names, the Old Icelandic Pórr and the Runic Danish Pur correspond to the form *PunraR ( appellative meaning 'thunder'). Different authors have reconstructed original forms that are slightly different in de- 
tail. Uku Masing has argued that the large number of attempts to reconstruct the original form of the name Pórr clearly demonstrates the lack of Indo-European etymology - something seems to be out of joints (Masing 1936: 6). The variety of interpretations is rather an indicator of the importance of the research subject and the different views of the scholars. Below I will demonstrate that Pórr is derived from the same Indo-European root.

A comparison of the names Donar and Punar-r reveals their obvious similarity. The indicated verbal root corresponds to the Latin form tono, tonare, meaning 'donnere, donnern' (Walde-Hofmann 1954: 690-691, Meyer-Lübke 1972: 728, no 8778), or 'thunder; speak thunderous tones/thunderously; make/resound like thunder'. On Scandinavian etymologies see also the Norwegian-Danish etymological dictionary: Torden, Pôrr, Indo-European root *(s)ten (Falk, Torp 1960: 1273f); the Icelandic etymological dictionary: 1. sten-, ten- (Indo-European root), Pórr (Jóhannesson, 1956: 872) and the Ancient Scandinavian etymological dictionary: Pórr, Indo-European root (s)ten (de Vries 1962: 618).

Thus, the Germanic name for thunder and thunder god can be traced back to the Indo-Germanic root (s)ten- 'von lauten Geräuschen: donnern, rauschen, dröhnen, stöhnen' (Pokorny 1959: I, 1021), sten-, ten- 'von Lauten Geräuschen: donnern, rauschen, brausen, dröhnen, stöhnen' (Walde-Pokorny 1930: II, 626f) or steno 'groan, moan' (Mann 1984-1987: 1284). The root has equivalents in Indo-Iranic languages: STAN 'roar', stánati 'roars', stanáyati 'thunders' etc.. (Turner 1966: 788), but also in Slavic languages, e.g. Russian стенать 'groan, wail, moan' and стон 'a groan, groaning, wailing' (Vasmer 1958: III, 10 $\& 19)$.

Consequently, there can be no doubt that Pórr is the same with Donar and that we have a perfectly acceptable and reliable IndoEuropean etymology. This means that the Scandinavian Pórr cannot be a loan from the Balto-Finnic languages. The original IndoEuropean root for rumble, roar, groaning and wailing has become to denote 'thunder' in Germanic languages and has, in its turn, resulted in the thunder god's name Donar = Pórr. And this is also the answer to Uku Masing's question. 


\section{THE CELTS, THE GERMANIC PEOPLE AND TAARA: TARANIS OF THE CELTS AND DONAR-PÓRR OF THE GERMANIC PEOPLE}

There have been accounts about thunder god Taranis (Taranus, Taranucus, Taranucnus) from the Celtic areas on the continent, and also about thunder god Tanaros; there have been accounts from Britannia and Tanarus, by Pliny in Gallic, which was the name of the river Po in Northern Italy (meaning 'roaring, soughing, thunderous').

Jaan Puhvel has argued that the name of the Gallic thunder god, Taranis, is a cognate of the $u$-rooted *taranu-, or "thunder' in Old Gaelic and Cymric. He mentions that taran- is metathetic ${ }^{8}$ with the root tanar-, which occurs in the Latin inscription $\mathrm{J}$ (ovi) $\mathrm{O}$ (ptimo) $\mathrm{M}$ (aximo) Tanaro and is identical with the Germanic root *thunar'thunder' (Puhvel 1987: 169, 1996: 173).

People sacrificed the heads of the slain and burnt people to sacrifice to the Celtic thunder god Taranis (Leach 1992: 222). Tanaros, Tanarus was a local thunder god, who has been identified with Jupiter (see J O M Tanaro above). There are reports of him from the Gallic and British areas (Leach 1992: 221).

There are two main approaches to discussing and interpreting the Celtic thunder god(s) Taranis, Tanaros (see Vendryes 1981: T-143). According to the first Tanaros is identical with the Germanic god Donar-Pórr and these names have the same etymology (*DunaraR is etymologically corresponds to the Celtic root *tonar-(Tanaros)). According to this view, the root *toran- (Taranis) is a metathetic form of the former root (*tonar $>$ toran-). Jaan Puhvel also supports this theory, even though the view was questioned already in the last century (Stokes \& Bezzenberger 1979: 122).

The second approach perceives the name Taranis as an originally Celtic name, which should be viewed separately from the Germanic gods and etymology. The Old Irish Gaelic word for 'thunder, lighting' is torainn, the Modern Irish word is toirneach (though, torann means 'rumble'), in Cymric and Breton the word is taran. Also the Old Irish Gaelic word tairm 'rumble'; Lithuanian tarti 'to say', Greek

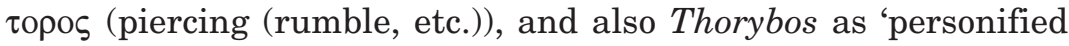


rumble'. Even Uku Masing has provided the etymology of the Celtic thunder god and thunder from the Indo-European root tor(o-s) and its cognates in other Indo-Germanic languages according to WaldePokorny (1930: I, 744) (Masing 1939: 14f). And here the same root appears once again: tor-, toro-s 'loud, audible; piercing (sound)' (Pokorny 1959: 1088-1089). ${ }^{9}$

According to this approach, Tanaros can, in fact, be associated with the Germanic pantheon, although an opposite metathesis *toran-> tonar-is also possible. Recent theories regard Tanaros and Taranis as the same name (Birkhan 1970: 313). ${ }^{10}$

Uku Masing tentatively agrees with the scholars who claim that the Germanic Thor has been borrowed from the Gallic (Masing 1939: 10). As I have demonstrated above, it may be possible; analogously, it may also be possible that the Celts borrowed their god from the Germanic tradition. However, there is no agreement on the matter. Further on, Masing suggests that both the Celtic as well as the Scandinavian names have been borrowed from the Finno-Ugric people (1939: 15).

We have already excluded the possibility that the Scandinavians borrowed their Pórr from the Estonians. Paul Ariste writes: "Next to the Baltic languages, the Proto-European substrate has been mentioned also in connection with Indo-European languages, especially the Celtic and Germanic languages. This explains the few common elements in the Baltic, Germanic and Celtic languages "(1981: 10). On the other hand, it is not known that the Balto-Finnic had any contacts with the Celtic people, and therefore the Celtic could not have borrowed anything from the Balto-Finnic people. The only way to connect Taara, Taranis-Tanaros and Donar-Pórr into a family of deities sharing common etymology would have to be based on the speculated linguistic and cultural contacts.

In terms of early linguistic and cultural contacts we also have to consider the Basque and Etruscan languages. It is assumed that the Basque is one of the extant Proto-European languages that were more widely spread in the past. The Etruscan language, with extant written records already from the pre-Christian period, also belongs among the Old European languages. The linguistic affiliation of the Basque as well as the Etruscan language has been a 
matter of wide speculation. Linguists, however, have agreed that both languages are isolates.

Jaan Kaplinski, the Estonian author, has attempted to argue in a newspaper article that Taara may have been an ancient Basque and North-European god (Sirp, February 6, 1998, no. 5 p. 7). He proves his point with a name of a Basque deity, Urtzi Thor in the works of a Basque writer Pío Baroja. Here the Basque god Urtzi is compared with his equivalent in another culture, Thor. The god known by the name Thor is not known in the Basque language, whereas Urtzi (Ortzi, Ostri, Ostiri) is a Basque god's name and derives from the meaning 'the vault of heaven, the luminance of sky'. From the 12th century a record Deum vocant Urcia, or "the god (of the Basques) is called Urcia", is known (Barandiarán 1973: 548).

Among the numerous Etruscan gods the one that interests us most is Tina (Tinia), who corresponds to Jupiter and Zeus. Tina was a sky god, who ruled over the northern and northeastern sections of the space. He could throw thunderbolts in each direction, whereas other gods were not allowed to do that (Leach 1992: 68).

According to Eduard Hrkal the Romans equated the day and thunder god Tinia (Tin) with Jupiter. He derives the god's name from an Old Etruscan word tin, and relates it to the Turan ${ }^{11}$ word tin, derived from tïn, which translates as the German Geist (spirit, ghost) in all the meanings of the word. But until the relation of the Etruscan language with any modern languages remains questionable, we cannot fully accept this etymology either.

Since we have no reason to assume that the Proto-European language spoken at the Baltic Sea before the arrival of the Finno-Ugric tribes might in any way be associated with the Etruscans or their language, then the material above is nothing but a mere speculation or illustration. I must admit that there is no evidence among the substrate phenomena on the possible link between Taara, Taranis-Tanaros and Donar-Pórr.

Some authors allow the idea of a common Indo-European thunder god, who was known from the North-European countries to Armenia. Joseph Karst, for example, associates the Nordic Pórr (Thor) with the pre-Christian Armenian deity Tork (Thorkh) and views them as identical (Karst 1931: $604 \mathrm{f}$.). Based on the forms Thor and 
Thorkh, he has reconstructed a pre-Indo-European thunder and storm god *Thorqvin. Pórr would then be just an apocopated form from the original *Thorqvin. Karst argues that the Illyrian-Albanian drek (trek), or 'devil', is also a pale reflection of the same god. He derives the names from an Indo-European root $\sqrt{ }$ tro $\chi$, tork, denoting 'the (world) circle'. Other authors have not supported this etymology and it is regarded as a mere speculation. ${ }^{12}$

Still, we have no reason to speculate on the influence of the common Proto-European thunder god, suggested by Karst, to the formation of Taara or other names of Celtic or Germanic thunder gods. Now, let us expand our view and turn to the analogous names of (thunder) gods in the Altaic and other distant traditions.

\section{POLYNESIAN AND ALTAIC GODS}

Uku Masing writes:

We could view our god name [Taara] among a very wide circle of associated words, but all these words differ at least to the degree that it is impossible to determine whether the Estonian word is related or not. First the Ostyak [Khanty] Tôrâm, the Vogul [Mansi] Toorm, Torim, the Chuvash Tora, the Turkish Tare [?], the Mongolian, the Turkmen, the Uyghur, the Tatar Tängere, Tengri, Tenger, the Kirghyz Tangri, the Yakut Tangara and the Sumerian di(n)gir as well as the Polynesian Tangaroa (Masing 1995: 47).

I will now focus on the Polynesian and Altaic god names and will return to the Khanty and Mansi god names in the next chapter.

The index of Marjorie Leach's (1992) The Guide to the Gods includes nearly 19,200 gods and deities, 1,750 of them beginning with letter T. The number of Tar-initial words is 41 , and the number of names beginning with Tor-24. Since the number of gods in the world is significantly larger than the number of phonemes in human languages, similar names inevitably occur by coincidence in different places of the world, either in Polynesia or Africa. Uku Masing, demonstrating his infatuation with Polynesian deities, categorises them exclusively in the Polynesian folk belief. I will therefore leave the Polynesian gods be and move on to the Altaic gods, who are closer to us by nature and by language. 
The common name for god in the Altaic languages is Tengri (Teyri), though Islam has virtually succeeded in eliminating the name from the vocabulary of Turkish and some other languages. I will point out some Altaic names: Turkish Tanri 'god', Mongolian тэнгэр 'sky, heaven, world, god, deity', тэнгэр дуу 'thunder, Uzbek тангри 'god'; the meaning of the Mongolian word тэнгэр refers to the original meaning of god's name among the Altaic people - 'sky'. The original meaning of the word 'sky', was very simple, and was used in sentences like "The sun is up in the sky" or "The sky is covered by clouds". This original meaning is the source of the general name of god, which is a very typical development, indeed. The closest parallel would be the Finno-Ugric *ilma, or 'the weather, the world', which is the source for the name of the Balto-Finnic sky god Ilmarine. The original meaning of the word *tenri in many Altaic languages has been lost or substituted with the meaning god or deity. The word is used as an adjective as well, meaning divine, heavenly. It is believed that etymologically the word *tepri 'sky' derives from the verb denoting turning, change (Roux 1987: $401 \mathrm{ff}$.). On the Altaic sky god Tengri see also (Roux 1956, 1958, Räsanen 1969: 474, and Clauson 1972: 523 ff.).

\section{KHANTY AND MANSI SKY GODS, KARAGAS 'SKY' AND 'GOD' AND SAMI 'SKY GOD, THUNDER'}

"The uniqueness of an Estonian god would be proven by the existence of an analogous god among other Finno-Ugric traditions" (Masing 1939: 11). Let us now turn to the Khanty and Mansi sky gods that are analogous to Taara and observe the etymology of the general names.

Interesting accounts of the god Tarom-Torom can be found Peter Simon Pallas's comparative dictionary published in 1789 (Pallas 1977: 2, 5). ${ }^{13}$ In the Mansi dialects (no. 66-69) the word appears as Taroms / Saireng b-Taromb, Tarmъ, Tóroms and Torymъ. Only once (no. 66) has the same word been used to denote sky: Táromb. In Khanty dialects (no 70-74; the word is not included in no 75) the word for god is Torómb, Tormb, Toromb, Toroms and Toroms / Torms; the word for sky Toromb, Numb-Tóroms and Toromb-Iomъ. On one occasion (no 70) the word was used to denote thunder - Tóromb-Tuts (with Cyrillic soft signs). Things would be clear and simple, if the word for 
god Nobъ in no. 130 in Karassin (supposedly Karagas) language had not had a parallel word Teere or the word for sky Tits a parallel teere.

In the etymological dictionary of the Khanty dialect the name Torəm is defined as '(supreme, often Christian) god, guardian spirit, saint, image of a saint, icon; sky, weather, storm; world; time'. The book does not provide etymology for the name Toorem, but makes a reference to the analogy with the form and meaning of the Mansi name. An interesting detail states that the word торомin Russian is a loan from the Khanty dialect (Steinitz $1966 \mathrm{ff} .: 147 \mathrm{ff}.){ }^{14}$ The Mansi name Tårem [torem] has the meaning of 'god, sky; time, season; world, weather’ (Munkácsi \& Kálmán 1986: 657 ff.).

K. F. Karjalainen argues that the origin of the name Torem is obscure. According to him the word has been related to the Sami word diermes 'thunder', it has been regarded a loan from the Turkish-Tatar word tayri 'sky', or an equivalent of the Hungarian words árnyék 'shadow' or terem 'to appear, to arise, to generate'. Karjalainen himself seems to allow the first interpretation, though he admits it is questionable (Karjalainen 1922: 292). Uku Masing agrees that the Khanty and Mansi words might be related to the Sami word diermes, to which he reconstructs an analogous Estonian equivalent teerm. He has not, however, made any reference to whether Taara and teerm are related. Masing argues that the $m$-grapheme in the Sami words Dierbma, dierma 'rainbow, thunder' and Diermes, dierbma 'thunder' is a suffix (Masing 1939: $11 \mathrm{ff}$.). Ivar Paulson notes that the etymology of the Khanty and Mansi word Torem is still unclear and refers to the mentioned work by Karjalainen (Paulson 1962: 61).

In the following I will present the Altaic (Turkish-Tatar) etymology of the Khanty-Mansi Torem.

The Khanty and Mansi tribes are believed to have arrived from the South-Ural steppe to their present habitat around the mid-1st millennium A.D. They had contacts with the Altaic tribes already in their original home and have maintained a steady contact with the Tatar people on the southern border of their present habitat. Paul Pelliot has demonstrated how the Turkish word tängrim 'my god' (Possessive) has undergone word-internal contraction and produced the name form Tärim (Terim) (1914: 498: 1944). Gerald Clauson has 
agreed with Pelliot's argumentation and has stated that teyrim denotes 'my god' and terim is 'a royal title or an addressing formula' (Clauson 1972: 524 \& 549).

By analogy we may assume that the Khanty and Mansi derived their word for sky and god Torem from the Turkish word teprim 'my sky, my god', which then underwent word-internal contraction, rather than from the Turkish form tängri 'sky, god'. Though, it is also likely that Torem was a loan from the already contracted possessive forms tärem or terem.

Recent authors since Pallas have made no reference to the Karagas word for god, Teere (teere, or 'sky'). According to an earlier account by Pallas from 1772, the Karagas god is also called Tere and the word for sky was also Tere (Pallas 1967: 375). He writes in his travel notes that "the most noteworthy tribe, the Karagas tribe, which, like the Koibals and the Motors at the Yenissei, have preserved the Samoyed language (influenced to a small degree only by the Mongolian and Tatar languages), consists only of 22 adult male members. [---] Their [The Karagas] beliefs [---] are the simplest in the world; they know neither witches nor idols, but address their prayers to the sky and the sun" (Pallas 1967: 304). ${ }^{15}$

We may consider likely that the Karagas Tere, Teere are a relatively recent loan from the Altaic languages (Tuva). The loan would correspond to the Altaic form tärem, terem, without the possessive $-m$ suffix. The function of $-m$ as a possessive suffix is evidenced by the fact that in the Khanty and Mansi languages the name of Torem was written with a word-ending hard sign, which indicates that the preceding consonant is not palatalized [see Note 13]. In Modern Turkish language the possessive suffix $-m$ is always pronounced. The relation of the Khanty and Mansi Torem with the Sami words Dierbma, Diermes (or Tiirmes in present-day Kola-Sami literary language) and the possible Estonian equivalent teere- $m$, reconstructed by Uku Masing, still remains questionable. Now, if we compare it with the Karagas word teere, we will inevitably encounter new questions and doubts.

Let us assume that Teere was not a recent Altaic loan, but a word of Uralic or Uralic-Altaic origin, and was related to the Estonian Taara, Sami Tiirmes (Diermes) and Khanty-Mansi Toorem. The 
Altaic word for god is Tangri, Tayri or 'god, sky', and it supposedly derives from the verb denoting turning, change. Is there analogy in the Finno-Ugric languages?

Here it is interesting to note that sometimes the Livonian place name Thoreyda, Thoreida (English Treiden) attested in the Chronicle of Livonia is interpreted as the garden of Taara - Thor 'Taara' + *aida 'garden'. If this interpretation is true, the theonym Taara was also known in Livonian.

Björn Collinder presents the list of common Uralic-Altaic roots (the B list with Finno-Ugric and Altaic equivalents, no 58), including the Finnish hiiri (*šinere) 'mouse' // the Manchu singeri 'rat', the Nanai si?gar and the Evenki sinõrõ-kõõn 'mouse, rat' (Collinder 1955: 148). In the etymological dictionary of the Uralic languages the FinnoUgric word for mouse (Estonian 'hiir') is presented in the form šine$r e$, where -re would function as a denominal noun suffix (derivation of noun from noun), and is therefore set in correspondence with the Manchu-Evenki *sine-re 'mouse, rat', whereas the borrowing may have taken place in both ways (Rédei 1988: I, 500). See also Räsänen 1969: 109a \& 416a. The parallel between the tengri / teyri $\rightarrow$ taara and singere / sinere $\rightarrow$ hiir, gen. hiire would be convincing, had the nasal component $-\eta$ - not been retained in the Ugric languages: the

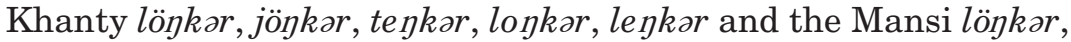
jönkar, tejkar, lonkar, leykar (also the Hungarian egér). The FinnoUgric example therefore may convince us that the Estonian taara and the Sami teer-m (and the Southern Samoyed Karagas tere, teere) correspond to the Altaic form teyri, but it says nothing about the Khanty-Mansi words tarem-torem.

If we look at the Uralic word nums 'supreme, sky, god', we can analyse its components $n u-m_{3}$, where $n u$ has the meaning of 'the upper part, supreme' and *-m 3 is a denominal derivational suffix, which forms a new noun from noun (Rédei 1988: I, 308f). According to Björn Collinder * $m$ is a typical determinative suffix of noun stem, which may be identical with the deverbative noun-forming ${ }^{*} m$ (Collinder 1960: 260, § 779; 266, § 799). The determinative suffix narrows the main word, thus narrowing the meaning of the term but expanding the contents. Here it might be a good idea to compare other words for sky and god: the Estonian jumal 'god', the Volga-Finnic juma 'sky, god', *-la being the derivational suffix; the 
Estonian ilm 'world, weather' and the FInno-Ugric deity Ilmarine, the Finno-Ugric word ilma 'sky, world, god'. ${ }^{16}$

While $-m_{3}$ in the word num 3 is clearly a derivational suffix, we can only state that the ending syllable in the words ilma and juma is - ma. We may speculate that the nasal component is somehow connected to the name or notion of god in the Uralic languages and may occur as a suffix, or influence in some other ways the choice of the god's name. Perhaps our ancestors used to hum while contemplating about god or solemnising in rituals? If so, then the speculation could explain the presence of $-m$ suffix in the Sami word for thunder teer- $m$ and the Khanty and Mansi words tare- $m$, tore- $m$. The $-m$ element may even be regarded as a theonymic segment analogous to the Slavic segment -vit.

While the Uralic * $m$-suffix may originally have been both denominative as well as deverbative, then we may speculate, while bearing in mind that the Altaic tenri 'sky, god' was originally a verb denoting change and turning, that if we have the common UralicAltaic verb-stem *teyri, then the deverbative ${ }^{*} m$ suffix may have formed from what changed and turned in the sky the notion teyri-m 'sky' itself. Much like the verb-stem või- (>*voi-) 'can, be capable of' in the Estonian language is the source of the Estonian noun võim 'power, control, force, might'. Later the noun teyri-m became to signify god, in some cases also thunder and the internal nasal component was lost. In the Estonian language the word may have also lost the deverbal suffix $* m$, resulting, through many vowel shifts, in Taara. We have to remember that the belief in the turning world or firmament was common in the whole North-Eurasia, also among the Uralic peoples. And this is not far from the momentarily stable notion of sky and god.

Mathias Alexander Castrén pointed out already in 1852 that Estonian Tara, Sami Tiermes (stem Tierm, Dierm, Djerm) 'sky god', Khanty Turm (Torm, Torom), and Chuvash (a Turkish group, influenced by Finno-Ugric, Russian and Tatarian) Tora may belong together. He also speculated that in Estonian and Sami sky god have had two personal names: Sami Jubmel (Ibmel) and Tiermes and Estonian Jummal and Tara (Castrén 1852: 216-217).

Also Juha Pentikäinen puts the name of the thunder god, Dierpmis or Tiermes, of the Skolten-Sami and Samis in Kola Peninsula, and 
partly in Finnmark and at the Polar Sea coast, in connection with the Ob-Ugric Toram (Khanty Turam and Mansi Taram) (1998: 766). It should be noted here that the name Tiermes and its variants are not borrowed from Scandinavian Thor. Thor gives Hora in Sami languages, e.g. Horagállis, Horan Galles, Hora Kaales, and Horagalles have meaning 'Thor, the Elder'.

In his manuscript "Fragmenter i lappska mythologin", Lars Levi Laestadius (1800-1861), a clergyman, advocate of sobriety, naturalist, philosopher and founder of a revivalist movement, wrote in 1840 that according to some earlier scholars, Thiermes was the supreme god of Sami people, he reigned thunder and rainbow, but also human health and life, weather and winds, sea and water. Sami people sacrificed him to get the sea storms under control (see Læstadius 1994: 57, Laestadius 2000: 67-68).

\section{TARACONTAAND TAARA}

We may accept with relative confidence that Turupið of the Knytlinga Saga is Taarapita of the Oeselians. Now, are there even earlier written records of Taara or Taarapita?

The Cosmography of Aethicus (formerly known as Aethicus Ister or Istricus), written in the middle of the 8th century or even later, mentions the islands Rifargica (Rifarica, Riffarrica) and Taraconta (Wuttke 1991, Prinz 1993). ${ }^{17}$

The new edition edited by Otto Prinz relies on the comments by Kurt Hillkowitz, who concedes that Rifargica (Rifarrica) insola may refer to the coast of Estonia, though he considers it somewhat unlikely (Hillkowitz 1973: 143-144, Comment 228). I tend to agree with P. Wieselgren's, Gustav Mets' and Lennart Meri's views that the island of Rifargica described by Aethicus points to the coastal region of Rebala (Rävala) (Wieselgren 1947: 114, Must 1951: 310, Meri 1976: 116).

Lennart Meri has linked the Rifarrica "island" with the island of Taraconta and theorizes that these must have been located close to each other. ${ }^{18} \mathrm{He}$ draws attention to the second half of the name conta and explains it through the Balto-Finnic word -kond, -kund, 
meaning 'whole, entirety'. At the same time he makes no reference to the first half Tara- of the name Taraconta (Meri 1976: 116).

The different manuscripts of Cosmography also include the forms Tareconta and Tharaconta. Otto Prinz notes in a footnote to his edition that Taraconta is an unfamiliar name signifying island, a great city on the island, and a tribe (people) (Prinz 1993: 120, Comment 192). Heinz Löwe has come up with different interpretations for the name Taraconta: he appears to believe that the island of Taraconta was inhabited by the Turks (1975: $133 \mathrm{ff}$.). For earlier assumptions on the meaning of Taraconta, see Wuttke 1971: xxxi.

If Rifargica stands for the coastal region of Rebala, which is very likely, then - regardless of other ways of interpretation - it is highly likely that Taraconta (Tharaconta) stands for the island of Oesel. This is supported by the evidence that the better known languages have not provided an etymology for the name Taraconta, but the Balto-Finnic languages are and always will be illegible for most scholars. Territorial units ending with -kond are relatively common in the Estonian language, such as the words kihelkond 'parish' and maakond 'county', or specific names for former counties Nurmekund (Nurmegunde) and Kihelkond (Kielkond, Kiligunde) in the western part of Oesel, which has been retained in the place name Kihelkonna. The suffix -kond is also used in words indicating a collective body, such as malevkond (väehulk) 'army host', kümmekond 'ten or so', sadakond 'hundred or so', perekond 'family', hõimkond 'kindred', põlvkond 'generation', etc.

The word kunta definitely dates back to the Finno-Ugric period, perhaps even to the Uralic period, when it signified gender, family, generation, or any group in general (Rédei 1988: I, 206). The only problem is that in the Balto-Finnic languages the word kunta is also used in toponyms. I will discuss this point for a moment.

Because of its occurrence in the names of geographical and territorial units, the word kunta is often considered a Germanic loan from the Old Scandinavian word hunda, meaning 'hundred' and 'crowd, multitude', such as in Att-hunda-land (Karsten 1936: 485). This shift in the meaning of the word kunta is sometimes explained by the Germanic influence on Balto-Finnic languages (Rédei 1988: I, 206). Farkas, however, considers the word kunta in the words like the 
Finnish valtakunta 'state' Finno-Ugric by origin (1954: 330). Jacob Grimm in his Deutsche Rechtsaltertümer (German Legal Antiquities) indicates that the word huntari (hundert 'hundred') had a dual meaning in administrative sense. On the one hand huntari corresponded to the subdivisions of a larger region (Tacitus pagi, Germanic gaue, German Gau), and on the other hand it signified a larger administrative unit consisting of smaller divisions, rather than a small divisional unit (Grimm 1989: $56 \mathrm{ff}$.). There is no doubt that the dual administrative meaning of the word kunta is a Germanic loan.

Hence another important conclusion - this knowledge enables us to give a rough estimation of the age of counties and parishes. Paul Johansen in his study on the Old Scandinavian name for presentday Oesel, Ösel (Estonian Saaremaa) [<*Eysýsla], speculates that on the Oesel Island and in continental Estonia parishes as administrative units may have appeared already in the $9^{\text {th }}$ century (Johansen 1950: 108). Since the Germanic administrative word hunta (hunda) corresponds to the Balto-Finnic kunta (kunda), we can assume that it was a relatively early loan and can be dated back to the 1 st centuries A.D. at the latest. Had the loan been more recent, then the Balto-Finnic people would have already adopted the $h$-sound and would have pronounced the word as hunta. In the early loans, as a rule, the Germanic $h$ is substituted with $k$, such in the Estonian words kana 'hen', kalju 'rock', kaer 'oat'.

Consequently, we may assume that in geographical and administrative names the word kunta is derived from the Germanic hunta, which was facilitated by the similar meaning - a body, mass, entirety of people. Such interpretation is supported by the dual administrative meaning of the word kunta - parishes, and counties consisting of parishes. Analogous administrative units may have been known already about the time when Christ was born or when Tacitus wrote his Germania. In the $9^{\text {th }}$ century A.D., under the Scandinavian influences, some units formed into parishes based on contract.

The Estonian word kihl is a Germanic loan (< Old Germanic *gisla, cf. to Modern German Geisel 'hostage') and means also pledge, pawn, agreement. This meaning has been retained, for example, in Modern Estonian words kihlvedu 'bet', also kihla vedama 'to bet, wager' (to make an agreement), kihlvedu pidama (i.e. to keep on to the 
bet), in other words, people make a bet and whoever surpasses the other, wins a pledge. Kihlused, or betrothal is an act for making an agreement to hold a wedding, i.e. arranging a marriage. The engagement ring given at the betrothal is nothing other than a pledge. Kihelkonnad, or parishes, are the territorial units, which were formed after the collapse of the tribal system and which are bound with contracts and the obligation to hand over hostages. Cf. also the Finnish kihlakunta, 'domain of judicial power'.

Returning to the Taraconta (Tharaconta) issue, we will see that kunta may have been used as a name for administrative units even before the 9th century, when the kihelkonnad or kihlkonnad (parishes) were established. This could even be seen as a kind of an administrative reform, during which the old names were replaced by the new ones. Interestingly though, in Oesel the general name kihelkond became a proper place name-Kihelkonna. We could speculate that the early *Taarakonda, a collective name for people connected to the supreme god Taara, became the contractual parish Kihelkonna.

In the 8th century the name Taarakonda (or Taraconta, Tharaconta, as Aethicus put it) may have signified the whole or a part of the island of Oesel. In the latter case the name Taarakond did not comprise the site of the Kaali meteorite crash. Either way, we may assume that Taarakond signified the whole western part of the island, which in the 9 th century became to be called Kihelkond, and the name has been retained in the form Kihelkonna. Further on the subject see Moora \& Ligi 1970: 65. On the place name Kunda with some references see also Kettunen 1955: 23, no. 553).

It is therefore possible that Aethicus recorded the name of Taara (Tara, Thara), the great god of the Oeselians, already in the mid8th century, when the Oesel Island, or its western part, may have been called Taarakonda (Taraconta).

\section{WHAT DO THE WORDS TAARA, PITA AND TAARAPITA ACTUALLY MEAN?}

Taara. The Nenets word tir denotes a cloud, the phrase tir num?, for example, means 'the clouded sky'. The word tir is clearly re- 
lated to the word tir?', which means 'the highest place (in comparison with the lower place); the upper surface; hillock or hill'; and is also related to the verb-stem tir- 'to fly'. Originally, the word may have had the meaning 'high, upper'. Semantically we may associate the Nenets word tir 'cloud < high, upper' with the Kola-Sami word cluster *teer-m (Dierbma, dierma, Diermes, dierbma, or the literary Tiirmes) meaning 'god, rainbow, thunder'. If we add the Karagas Teere 'god, sky' and the Khanty-Mansi Torem and the Estonian Taara, we could reconstruct the original form * $t 3 r 3$, where 3 marks an indefinite short or long vowel, with the meaning 'high, upper'. The ${ }^{*} m$ in the Sami and Ob-Ugric names would then be a conditional theonymic segment.

Such reconstruction is grounded since the Uralic word-initial *t has remained the same in the Samoyed as well as the Finno-Ugric languages. However, in the Nganassan language the equivalent word for the Nenets tir 'cloud' is črry $u$ ? 'cloud'. We may assume that the original form of the Samoyed word for 'cloud' began with *č. In the Samoyed languages the affricate has regularly changed into ${ }^{*} t$, and lost its $\check{s}$-ending. We may assume that in the Nganassan word the original affricate has been retained for some reason. The Balto-Finnic equivalent to the Uralic * ${ }^{*}$ is ${ }^{*} h$, since here the initial component $t$ was lost first and the regular change $\breve{s} \rightarrow h$ took place later (in the Sami language $\check{s}$ turned into $c$ ). In this case the Estonian Taara and the Sami *teer- $m$ cannot be related to the Samoyed words for 'cloud'.

However, the Nganassan word-initial $c$ could well be a later irregular development, which is evidenced by several parallel forms of Nganassan words beginning with $\breve{c}$ or $t$. A particularly good example is the Nganassan word čúo 'bird wing', which counterpart in the Nenets language is to 'bird wing'. The original Uralic form of these words is *tulka 'feather, wing' (Rédei 1988: I, 535).

Hence we may hold on to the idea that the Finno-Ugric and Samoyed words belong to the common Uralic word family. In the North Samoyed languages the word for 'high' or 'upper' became to signify 'cloud', in the South Samoyed languages (Karagas) as well as in the Ob-Ugric languages the word became to signify 'god', in the Sami language(s) it was used in the meaning of god, thunder or rainbow, and in the Balto-Finnic languages (Estonian) as a name of the su- 
preme god. Taara is therefore a god, who is high or supreme and whose place is high up in the sky.

Pita. Uku Masing has not addressed this matter, as he interpreted the name Taarapita as "Taara avita!" (Taara, help!) - a theory, which I have already rejected. Lennart Meri has been quite close to the truth in his interpretation of Taarapita as 'Taara's thunder'. The stem pita is traceable back to the Uralic root pide 'high, tall', which has appeared together with denominal noun suffix $-k \ddot{a}$ since the

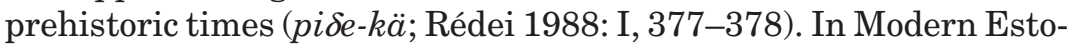
nian the word for 'tall' is pikk. The word form is relatively new: quite recently the word pitk, genitive form pitka was used (this form is still used in dialects). The word pikk derives from the form pit-ka ( $-k a$ being the same suffix mentioned above) by the assimilation of the root consonant: pik- $k$.

Pikne, or thunder, has also been derived from the same root *pitke-ne > pikne. In the J. Wiedemann Estonian language dictionary the modern word pikne means piken, pikene, piker, pikerlane, piknik and pitkes, pitkne. Words in the former group have already undergone assimilation $t k: k k$, while words in the latter group have not. However, assimilation has not taken place in the opposite direction, i.e. $t k$ : $t$. Therefore, there is no reason to equate the word pita with pikne, or thunder. Apparently, pita is nothing other than a simple root which corresponds to the Uralic root pide. Before we will look into the meaning of the root, let us observe some of its Estonian and Finnish derivations. The root without the $* k$-suffix has given the participle adjective pidev 'constant, lasting' in Estonian, and pitevä 'tall and narrow, thin' in Finnish. Especially interesting are the degrees of comparison of the Finnish word pitkä, or 'tall': comparative pitempi ( pidempi) 'taller' and superlative pisin 'the tallest'. Both the comparative as well as the superlative forms have been formed from the root without the $* k$-element, and the apparent loss of - $t$ - in superlative is caused by the regular BaltoFinnic sound shift $t i \rightarrow s i$. This may have happened in the root under discussion after the end vowel *pite had fronted to $i$ : *piti. These examples clearly demonstrate that the Balto-Finnic stem *pite may have occurred without the $k$-element. The Balto-Finnic descriptive pisi(ke) ('tiny' in Estonian) and the Finnish pisku may very well be the derivative of the variant *piti >pisi from the stem *pite, like the 
superlative form pisin from the Finnish word pitk $\ddot{a}$ 'tall'. The only question that remains is the alteration of the ending vowel $e \sim a$ : *pite pita. This problem can be solved, because in Estonian many adjectives with $a$-stem often have the comparative form with $e$-stem, e.g. must : musta (gen.) : mustem (superlative); pikk : pika (gen) : pikem (superlative).

What could the reconstructed root *pite, which also appears in the word pita, mean? What is the common characteristic in the words pikk 'tall', pidev 'lasting, constant' and pisike(ne) 'tiny'? Probably degree, or measure. In related languages the root *pide has also additional meanings, such as 'large, size', such as the Kamas purže 'state, shape; high, large', and the Tazi (a dialect of the Selkup language) piri 'height, size'. Herein lies the key to explain the meaning of pita - the root may have the meaning 'big, large, great', both in the abstract sense as well as specifically in relation to the height, strength, might, greatness and size.

The name Taarapita could therefore be interpreted predicatively as an incomplete sentence "Taara (is) great", or attributively as 'Taara, the Great'. Or, as the Chronicles of Henry reads: ubi erat monset silva pulcherrima in qua dicebant indigene MAGNUM DEUM Osiliensium natum, qui THARAPITA vocatur, et de illo loco in Osiliam volasse. ${ }^{19}$

\section{CONCLUSION}

The meaning of the name Taarapita may be 'Taara (is) great' or 'Taara, the Great'. The epithet pita, meaning 'great, large, big' is of Uralic origin. The etymology of the name Taara, however, remains incomplete: Firstly, it may have been borrowed from the name of the Scandinavian thunder god Pórr; secondly, it is possible that the Estonian Taara, the Sami Tiirmes 'sky god, thunder' and the KhantyMansi Torem 'sky, god' have been borrowed from the possessive form of the Altaic god's name te yrim 'my sky, my god' (in such case the Estonian Taara does not belong to this group and may still be considered a Scandinavian loan); and thirdly, Taara may belong to a group of Uralic-Altaic or Finno-Ugric - Altaic common words, and the ${ }^{*} m$ element in the Sami and Khanty-Mansi names are conditionally theonymic. The South Samoyed Karagass word Tere, Teere 
'sky, god' may belong to the latter group of words, but may also be a more recent and independent loan from the Altaic languages (Tuvan). I tend to favour the third possibility, according to which Taara is an original Finno-Ugric word for god, which has developed parallelly with the Altaic equivalent te pri.

The fourth, and the most plausible theory is that Taara is of Uralic origin and is a derivation of the root $* 3 r 3$, which originally meant 'high, upper'. This theory groups together the Estonian Taara, the Kola-Sami Tiirmes, the Khanty-Mansi Toorem, the South Samoyed (Karagas) Tere, Teere and the North Samoyed Nenets tir 'cloud < high; to fly' and the Nganassan čir ${ }^{y} u$ ? 'cloud'. Also the Chuvash (a Turkish group, influenced by Finno-Ugric, Russian and Tatarian) Tora and Livonian Thoreyda, Thoreida may belong here.According to this interpretation Taara is god who is on a high position.

The island of Taraconta (Taarakonda) mentioned in the middle of the 8th century in Cosmography attributed to Aethicus very likely points to Oesel (the island of Saaremaa). Also, Turupid, mentioned in the Knytlinga Saga (1168 or 1169) can be identified as Taarapita. The Latin text of the Chronicles of Henry of Livonia includes a name form Tharapita (Taarapita). (The Livonian place name Thoreyda, Thoreida attested in the same Chronicle is sometimes interpreted as the garden of Taara.) This Chronicle also include the interpretation of Taarapita as 'Taara (is) great' or 'Taara, the Great' is identical with the account from the Chronicles of Henry that Taarapita was the Great God of the Oeselians.

\section{Comments}

${ }^{1}$ Oeselians are the people of Oesel (Saaremaa Insel) in Estonia. I feel an obligation to thank everyone, who have read and commented on the manuscript. I have tried to take the criticism into consideration. I would like to express my special gratitude to Mr. Jaan Kangilaski for his help and support for translating the manuscript. The English version of this paper is rewritten with the help of the Estonian Science Foundation grant no 5292 "Structure and development of the theological and religious vocabulary of Estonian". And last but not least, my special thanks belong to Dr. Mare Kõiva from Estonian Literary Museum.

${ }^{2}$ Unfortunately, I cannot rely on the Estonian etymology of the word. Alo Raun has stated the following: "taara (religion) cf. Swed. Thor" (1982: 
168); the same can be found in the Estonian-English dictionary by Paul F. Saagpakk: "Taara - myth. chief god of the ancient Estonians ... cf. Scandinavian Thor" (1982: 915). The etymological dictionary by Julius Mägiste includes articles: taara III 'tare, empties', followed by taarausuline 'believer of Taara' (1983: 3028). Articles $I$ and II are missing. The missing page (3027) has been restored in the new edition of the dictionary (2000), but the article taara II 'Taara' does provide neither a definition nor the etymology of the word (taara I means tagger). Likewise there is no help from the Analogical dictionary of the Estonian language by Andrus Saareste, which lists under the heading Divinity also Taara, Toor and Tarapita (Saareste1958: 762 ff..).

${ }^{3}$ Hereinafter all Latin quotations from Arbusow \& Bauer (1955) edition of the Chronicle of Livonia. The English edition of the Chronicle (Brundage $1961 \& 2003)$ is a good literary translation with unfortunately low scientific value. The translations into English follow the Brundage's text in general. The spellings of the name Taarapita follow the edition of Arbusow \& Bauer in English translations of the quotations.

${ }^{4}$ An overview of the earlier analyses of the name Taarapita by Ants Viires (1990 \& 2001).

${ }^{5}$ A scholar interested in the topic may find it useful to consult both editions, not as much for the differences in translation, but because of the comments. The comments of the 1826 edition (repr. 1987) are far more thorough and sceptical. The comments of the new edition have allowed even the speculations about Estonia that the editor of the previous edition deemed ridiculous.

${ }^{6}$ On the 375th meeting of the Learned Estonian Society Kotljarevski (1871: 79) notes that his explication of the name Tharapita was introduced already in 1853 by Schiesner. He also makes a reference to a footnote comment in the work (Castrén 1853: 329). Apparently Grimm referred to the very same book in his above quotations (Grimm 1965: III, 35).

${ }^{7}$ Here we can also see that the double consonant at the end of the Scandinavian Pórr ( $r-r)$ is formed of the root consonant and the nominative ending.

${ }^{8}$ Metathesis is the transposition of letters, syllables or sounds in a word.

${ }^{9}$ The Gallic names of the rivers Taros and Tara are etymologically derived from the Indo-European root ter- 'to cross over, pass through' (Walde-Pokorny 1930: II, 732 f.). 
10 The names of Germanic as well as Celtic thunder gods are derived from roots associated with sound. A Baltic thunder god, the Lithuanian Perkunas, originates in a somewhat different root per-, per-g-, per- $q$ - 'to strike', though striking produces a sound as well (Walde-Pokorny 1930: II, $42 \mathrm{f}$.). The same root is in the Old Icelandic Fjorgyn 'Pórr's mother'. An overview of Indo-European vocabulary related to thunder is available in Buck 1949: $57 \mathrm{f}$., no. 1.56 Thunder. The Scandinavian Týr, the god of war and justice ( $-r$ is here a nominative ending), is, like other Indo-European sky gods, derived from the root dyews, deywos; the Estonian taevas, 'sky' or 'heaven', also derives from this root.

${ }^{11}$ What is meant by the Turan language are probably the sc. Uralic-Altaic languages. According to Eduard Hrkal the Etruscan would belong to the Uralic-Altaic language family.

${ }^{12}$ On the pre-Christian thunder god Tork see Ishkol-Kerovpian (1986: 141143).

${ }^{13}$ The dictionary is written in Cyrillic alphabet. The key to reading the text is provided in the beginning of the book on pages XVII-XVIII Explicatio literarum Alphabeti Rossici. The name forms that interest us can be transcribed one-to-one, except " . character in fine verborum adhiberi folitus, pro indicanda fortiore pronuntiatione ultimae consonantis" (which I will retain) and „Ы. aequipollet ypsilo graecorum” (which I will therefore substitute with $y$ ).

${ }^{14}$ For the sake of simplicity I will omit the diacritics from the Khanty and Mansi words, and will use the form Torem for the name in both languages (Author's comment).

${ }^{15}$ All these three Sayan Samoyed tribes and languages were Tuvanised at the end of the 18th century. The Karagas or Tofalar (620 people in 1970) living in the present-day Irkutsk Oblast, the Siberian federal district, are close in language and culture to their eastern neighbours Tuvans. By ethnicity they are partly the descendants of the Sayan Samoyed Karagas.

In his travel notes Pallas also describes the beliefs and divine service [Götzendienst] of the Khanty (1967: 59 ff.). According to him the Khanty name for god was Torom and Turum, and the Mansi name for god was Torom. He also refers to the god name among the Mordvins on the Volga River: “Tschw. Tora”, or "Tora of the Chuvash' (1967: 57).

${ }^{16}$ Károly Rédei has also recently indicated that in the Uralic languages (except for the Hungarian and the Mordvin) notions 'sky' and 'god' are expressed by the same words (1996). On the other side, Michály Hoppál wrote that there is no good explanation for the Hungarian term Isten 'God'. $\mathrm{He}$ also pointed out that A. Helimski and V. V. Ivanov have raised the interesting possibility of explanation Isten from the Old Hungarian word 
ise 'father' and Old Turkish tengri 'God, sky', i.e. Isten is God-Father or heavenly father (Hoppál 2000: 65).

${ }^{17}$ The actual author and date of origin of Cosmography is unknown.

${ }^{18}$ Let me remind you that even for Adam of Bremen Estonia (Aesthland) was an island among other Baltic and Scandinavian islands.

${ }^{19} \mathrm{p} .175$. There was there a mountain and a most lovely forest in which, the natives say, the GREAT GOD of the Oeselians, called THARAPITA, was born, and from which he flew to Oesel; 193f. (Capitalisation by the author).

\section{References}

Adam von Bremen 1986. Hamburgische Kirchengeschichte: Geschichte der Erzbischöfe von Hamburg. Übersetzt von J. C. M. Laurent \& W. Wattenbach. Alexander Heine (Hrsg.). Essen \& Stuttgart: Phaidon.

Adam von Bremen 1987 = M[eister]. Adam's Geschichte der Ausbreitung der christlichen Religion durch die hamburgische und bremische Kirche in dem benachbarten Norden, von Karls des Großen bis zu Heinrichs des IV. Zeiten; wie auch dessen geographische Abhandlung über Dänemark und über die daran gränzenden Länder des Nordens. Aus dem Lateinischen übersetzt und mit erläuternden Anmerkungen begleitet von Carsten Miesegaes. Bremen 1825. Reprintausgabe. Bremen: Carl Schünemann.

Arbusow, Leonid \& Albert Bauer (Bearb.) 1955. Heinrichs livländische Chronik. 2. Aufl. (Monumenta Germaniae Historica, 7, 31.) Hannover: Hahn.

Arbusow, Leonid \& Albert Bauer (Bearb.) 1959. Heinrich von Lettland: Livländische Chronik. Neu übers. v. Albert Bauer (Ausgewählte Quellen zur deutschen Geschichte des Mittelalters; 24.) Darmstadt: Wiss. Buchges.

Ariste, Paul 1981. Keelekontaktid. Eesti keele kontakte teiste keeltega. (Eesti NSV Teaduste Akadeemia Emakeele Seltsi toimetised; 14.) Tallinn: Valgus.

de Barandiáran, José Miguel 1973. Die Baskische Mythologie. In Hans Wilhelm Haussig (Hrsg.) Götter und Mythen im alten Europa. (Wörterbuch der Mythologie, 2.) Stuttgart: Ernst Klett, S. 511-552, Tafel I-VIII.

Beck, H. 1986. Donar-Pórr. In Johannes Hoops, Reallexikon der Germanischen Altertumskunde. 2. völlig neu bearb. Aufl. Bd. 6. Berlin \& New York: Walter de Gruyter, S. 1-7.

Birkhan, Helmut 1970. Germanen und Kelten bis zum Ausgang der Römerzeit. der Aussagewert von Wörtern und Sachen für die frühesten keltischgermanischen Kulturbeziehungen. (Österreichische Akademie der Wissenschaften. Philosophisch-historische Klasse: Sitzungsberichte, 272). Wien: Hermann Böhlaus Nachf. 
Brückner, A. 1925. Slaven und Litauer. In Alfred Bertholet, Edvard Lehmann (Hrsg.) Lehrbuch der Religionsgeschichte. 4. vollst. neubearb. Aufl., Bd. 2 Tübingen: Mohr, S. 506-539.

Brundage, James A. (transl.) 1961. The Chronicle of Henry of Livonia. Madison: University of Wisconsin Press.

Brundage, James A. (transl.) 2003. The Chronicle of Henry of Livonia / Henricus Lettus. With a new introduction. New York: Columbia University Press.

Buck, Carl Darling 1949. A Dictionary of Selected Synonyms in the Principal Indo-European Languages. Chicago: The University of Chicago Press.

Castrén, Mathias Alexander 1852. Was bedeuten die Wörter Jumala und Ukko in der finnischen Mythologie. Mélanges Russes. Tome 2, p. 175217. St.-Pétersbourg.

Castrén, Mathias Alexander 1853. Vorlesungen über die finnische Mythologie. St. Petersburg.

Clauson, Gerard 1972. An Etymological Dictionary of Pre-ThirteenthCentury Turkish. Oxford: Clarendon Press.

Clemen, Carl 1960. Les Baltes et les Slaves. In Histoire Générale des Religions. Tome 1. Paris: Quillet.

Collinder, Björn 1955. Fenno-Ugric Vocabulary. Stockholm: Almqvist \& Wiksell.

Collinder, Björn 1960. Comparative Grammar of the Uralic Languages. Stockholm: Almqvist \& Wiksell.

Cotterell, Arthur 1986. A Dictionary of World Mythology. New rev. ed. Oxford \& Melbourne: Oxford University Press.

Ehasalu, Epp, Külli Habicht, Valve-Liivi Kingisepp \& Jaak Peebo 1997. Eesti keele vanimad tekstid ja sõnastik. Tartu: Tartu Ülikooli Kirjastus.

Falk, H. S. \& AlfTorp 1960. Norwegisch-Dänisches etymologisches Wörterbuch. 2. Aufl., 2. Teil. Oslo \& Bergen: Universitetsforlaget \& Heidelberg: Carl Winter.

von Farkas, Julius 1954. Die gesellschaftliche Organisation der finnisch-ugrischen Völker im Lichte der Wortkunde. Saeculum. Jahrbuch für Universalgeschichte, Bd. 5, Heft 3, S. 329-335.

Grimm, Jacob 1989. Deutsche Rechtsaltertümer. Nachdr. 4. Aufl., Leipzig 1899. Bd. 2. Darmstadt: Wiss. Buchges.

Grimm, Jacob 1965. Deutsche Mythologie. 3 Bde. (1878.) Darmstadt: Wiss. Buchges.

Grimm, Jacob 1880-1888. Teutonic Mythology. 4 Vols. London: W. Swan Sonnenschein and Allen, George Bell and Sons.

Haavio, Martti 1970. Taraphita. Virittäjä. Nr. 2, pp. 120-132.

Handwörterbuch 1929/1930 = Handwörterbuch des deutschen Aberglaubens. Bd. 2. Berlin \& Leipzig: Walter de Gruyter.

Hillkowitz, Kurt 1973. Zur Kosmographie des Aethicus. Teil II. Frankfurt am Main: Vittorio Klostermann (the first volume of the book was published in Cologne in 1934). 
Hoppál, Mihály 2000. Studies on mythology and Uralic shamanism. (Ethnologia Uralica; 4.) Budapest: Akadémiai Kiadó.

Hrkal, Eduard 1947. Der etruskische Gottesdienst. Dargestellt nach den Agramer Mumienbinden. Skizze und Übersetzungen der bis jetzt analysierbaren Inschriften. Wien: Gerold \& Co.

Ishkol-Kerovpian 1986. Mythologie der vorchristlichen Armenien. In Hans Wilhelm Haussig (Hrsg.), Götter und Mythen der kaukasischen Völker. (Wörterbuch der Mythologie; 1, 4.) Stuttgart: Klett-Gotha, S. 59-160 \& Tafel I-VI.

Jóhannesson, Alexander 1956. Isländisches etymologisches Wörterbuch . Bern: Francke.

Johansen, Paul 1933. Die Estlandliste des Liber Census Daniae. Mit vollständigem Facsimile. Kopenhagen: H. Hagerup \& Reval: F. Wassermann.

Johansen, Paul 1950. Der altnordische Name Ösels als verfassungsgeschichtliches Problem. In Kurt Bussmann \& Nikolaus Grass (Hrsg.), Festschrift Karl Haff. Innsbruck: Wagner, S. 95-110.

Jónsson F. (ed.) 1954. Ex Historia regum Danorum dicta Knytlingasaga. In Monumenta Germaniae Historica. Scriptores 5, 29. Hannover 1892. Nachdruck. Stuttgart: Hiersemann \& New York: Kraus, p. 271-322.

Karjalainen, K. F. 1922. Die Religion der Jugra Völker. Teil II. Folklore Fellows Communications, Helsinki \& Porvoo, Vol. 11, Nr. 44, p. 1-386.

Karst, Joseph 1931. Die vorgeschichtlichen Mittelmeervölker nach Ursprung, Schichtung und Verwandschaft. Ethnologisch-linguistische Forschungen. (Elsass-Lothringischen Wissenschaftlichen Gesellschaft (Strassburg): Schriften, C, 3.) Heidelberg: Carl Winter.

Karsten, T. E. 1936. Zu den ältesten Völker- und Ortsnamen der Ostseeländer. In Helmut Arnitz (Hrsg.), Germanen und Indogermanen. Festschrift für Herman Hirt. Bd. 2. Heidelberg: Carl Winter, S. 471-492.

de Kay, Charles 1898. Bird Gods. New York: A. S. Barnes.

Kettunen, Lauri 1955. Etymologische Untersuchung über estnische Ortsnamen. (Suomalaisen Tiedeakatemian Toimituksia, B, 90, 1) Helsinki.

Kotljarewski, Aleksandr 1871. Eine estnische Gottheit als Gast auf der Insel Rügen. Sitzungsberichte der gelehrten estnischen Gesellschaft zu Dorpat: 1870. Dorpat.

Læstadius, Lars Levi 1994. Katkelmia lappalaisten mythologiasta. Toim. Nilla Outakoski. Tallinn.

Laestadius, Lars Levi 2000. Lappalaisten mytologian katkelmia. Toim. Juha Pentikäinen. (Tietolipas, 170.) Helsinki: Suomalaisen Kirjallisuuden Seura.

Leach, Marjorie 1992. Guide to the Gods. Ed. by Michael Owen Jones \& Frances Cattermole-Tally. Santa Barbara, California; Denver, Colorado \& Oxford, England: ABC-Clio.

Leger, L. 1896. Études de Mythologie Slave. Svantovit et les Dieux en «vit». Revue de l'Histoire des Religions. Tome 33, p. 1-18. 
Löwe, Heinz 1976. Salzburg als Zentrum literarischen Schaffens im 8. Jahrhundert. Mitteilungen der Gesellschaft für Salzburger Landeskunde, 115. Vereinsjahr 1975. Salzburg, S. 99-143.

Lõugas, Vello 1996. Kaali kraatriväljal Phaetonit otsimas. Tallinn: Eesti Entsüklopeediakirjastus.

Mann, Stuart E. 1984-1987. An Indo-European Comparative Dictionary. Hamburg: Buske.

Masing, Uku 1939. Taara päritolust. Usuteaduslik ajakiri. XI, no. 1, pp. $1-16$.

Masing, Uku 1995. Eesti usund. Tartu: Ilmamaa.

Meri, Lennart 1976. Hõbevalge. Tallinn: Eesti Raamat.

Meyer-Lübke, W. 1972. Romanisches etymologisches Wörterbuch. 5. Aufl. Heidelberg: Carl Winter.

Moora, H. \& H. Ligi (1970). Wirtschaft und Gesellschaftsordnung der Völker des Baltikums zu Anfang des 13. Jahrhunderts. Tallinn: Eesti Raamat.

Moszynski, Leszek 1992. Die vorchristliche Religion der Slaven im Lichte der slavischen Sprachwissenschaft. (Bausteine zur Slavischen Philologie und Kulturgeschichte. Reihe A: Slavistische Forschungen, N. F. 1 [61].) Köln, Weimar \& Wien: Böhlau Verlag.

Munkácsi, Bernát \& Béla Kálmán 1986. Wogulisches Wörterbuch. Budapest: Akadémiai Kiadó.

Must, Gustav 1951. Zur Herkunft des Stadtnamens Reval. FinnischUgrische Forschungen. Bd. 30, Heft 3, S. 303-311.

Mäger, Mart 1967. Eesti linnunimetused. Tallinn: Keele ja Kirjanduse Instituut.

Mäger, Mart 1994. Linnud rahva keeles ja meeles. 2. ed. Tallinn: Koolibri.

Mägiste, Julius 1983. Estnisches etymologisches Wörterbuch. 12 Bde. Helsinki: Finnisch-Ugrische Gesellschaft.

Mägiste, Julius 2000. Estnisches etymologisches Wörterbuch. 2. Aufl. 12 Bde. Helsinki: Finnisch-Ugrische Gesellschaft.

Pallas, Peter Simon 1967. Reise durch verschiedene Provinzen des Russischen Reichs. Nachdruck der Ausgabe St. Petersburg 1771-1776. Bd. 3. Graz: Akademische Druck- u. Verlagsanstalt.

Pallas, Peter Simon 1977. Linguarum totius orbis vocabularia comparativa. Bd. 1. Nachdruck der Ausgabe St. Petersburg 1786. Harald Haarmann (Hrsg.). Hamburg: Helmut Buske.

von Parrot, Johann Leonhard 1828. Versuch einer Entwicklung der Sprache, Abstammung, Geschichte, Mythologie und bürgerlichen Verhältnisse der Liwen, lätten, Eesten; mit Hinblick auf einige benachbarte Ostseevölker, von den ältesten Zeiten bis zur Einführung des Christenthums. Nebst einer Topographie und topographischen Charte des Landes zu Anfang des dreizehnten Jahrhunderts. Bd. 1. Stuttgart: Carl Hoffmann.

Paulson, Ivar 1962. Die Religionen der nordasiatischen (sibirischen) Völker. In Christel Matthias Schröder (Hrsg.) Die Religionen Nordeurasiens 
und der amerikanischen Arktis. (Die Religionen der Menschheit, 3.) Stuttgart: W. Kohlhammer, S. 1-144.

Pelliot, Paul. 1914. Une communication, I, $2^{\circ}$. Journal Asiatique. Onzième série. Tome 3, No. 2, Mars-Avril (Société asiatique. Séance du 13 Mars 1914, p. 497-500), p. 498.

Pelliot, Paul 1944. Tängrim > Tärim. T'oung Pao. Vol. 37, Livr. 5, p. 165-185.

Pentikäinen, Juha 1998. Die lappische (saamische) Mythologie. In Egidius Schmalzriedt \& Hans Wilhelm Haussig (Hrsg.) Die alten Kulturvölker. (Wörterbuch der Mythologie; 7, Lieferung 32.) Stuttgart: Klett-Cotta, S. 701-827.

Pokorny, Julius 1959. Indogermanisches etymologisches Wörterbuch. 2 Bde. Bern \& München: Francke.

Prinz, Otto (Hrsg.) 1993. Die Kosmographie des Aethicus. (Monumenta Germaniae Historica: Quellen zur Geistesgeschichte des Mittelalters, 14). München: Monumenta Germaniae Historica.

Puhvel, Jaan 1987. Comparative Mythology. Baltimore \& London: The Johns Hopkins University Press.

Puhvel, Jaan 1996. Võrdlev mütoloogia. Tartu: Ilmamaa.

Raun, Alo 1982. Eesti keele etümoloogiline teatmik. Rooma \& Toronto: Maarjamaa.

Raun, Alo \& Andrus Saareste 1965. Introduction to Estonian Linguistics. (Ural-Altaische Bibliothek, 12.) Wiesbaden: Otto Harrassowitz.

Rédei, Károly 1988-1991. Uralisches etymologisches Wörterbuch. 3 Bde. Wiesbaden: Otto Harrassowitz.

Rédei, Károly 1996. Über die Herkunft des ungarischen Wortes isten 'Gott'. Linguistica Uralica. Vol. 32. No. 4, p. 283-288.

Reiter, Norbert 1973. Mythologie der alten Slaven. In Hans W. Haussig (Hrsg.) Göttern und Mythen im alten Europa. (Wörterbuch der Mythologie; 1, 2.) Stuttgart: Klett, S. 163-208.

Roux, Jean-Paul 1956. Tängri. Essai sur le Ciel-Dieu des peuples altaïques. Revue de l'Histoire des Religions 149: 49-82, 197-230 \& 150: 27-54, 173-212.

Roux, Jean-Paul 1958. Notes additionales à Tängri le Ciel-Dieu des peuples altaïques. Revue de l'Histoire des Religions 154: 32-66.

Roux, Jean-Paul 1987. Tengri. In Mircea Eliade (ed.), The encyclopedia of Religion. Vol. 14. New York: Macmillan Publishing Company-

Räsänen, Martti 1969. Versuch eines etymologischen Wörterbuchs der Türksprachen. (Lexica Societatis Fenno-Ugricae; 17, 1.) Helsinki: Suomalais Ugrilainen Seura.

Saagpakk, Paul F. 1982. Eesti-inglise sõnaraamat. Estonian-English dictionary. New Haven \& London: Yale University Press.

Saareste, Andrus 1958. Eesti keele mõisteline sõnaraamat. Dictionnaire analogique de la Estonienne. Kd./Tome 1. (Eesti Teaduslik Selts Rootsis väljaanne; 3.). Stockholm: Vaba Eesti. 
Steinitz, Wolfgang 1966jj. Dialektologisches und etymologisches Wörterbuch der ostjakischen Sprache. Berlin: Akademie-Verlag.

Stokes, Whitely \& Adalbert Bezzenberger 1979. Wortschatz der keltischen Spracheinheit. 5. unv. Aufl. nach 4. Aufl. 1894. Göttingen: Vanderhoeck \& Ruprecht.

Tarvel, Enn (toim.) 1993. Henriku Liivimaa kroonika. Tõlk. Richard Kleis. Tallinn: Olion.

Toporov 1989 = Топоров, В. Н. Нз славянкой языческой терминологии: индоевропейские истоки и тенденции развития: Этимология 1986-1987. Москва: Наука, стр. 3-50.

Trubacev, O. N 1994a. Überlegungen zur vorchristlichen Religion der Slaven im lichte der slavischen Sprachwissenschaft. Zeitschrift für Slavische Philologie 54: 1-20.

Trubacev $1994 \mathrm{~b}=$ Трубачев, О. Н. Мысли о дохристианской религии славян в свете славянкого языкознания. Вопросы языкознания 43/6: 3-15.

Turner, R. L. 1966. A Comparative dictionary of the Indo-Aryan Languages. London: Oxford University Press.

Vasmer, Max 1958. Russisches etymologisches Wörterbuch. 3 Bde. Heidelberg: Carl Winter.

Vendryes, J. 1981. Lexique Étymologique de l'Irlandais Ancien (Letters T - U par les soins de E. Bachellery \& P.-Y. Lambert, 1978). Dublin: Dublin Institute for Advanced Studies.

Viires, Ants 1990. Taara avita! Looming, nr. 10, lk. 1410-1421.

Viires, Ants 2001. Taara avita! Kultuur ja traditsioon. Tartu: Ilmamaa, lk. 48-68.

de Vries, Jan 1962. Altnordisches etymologisches Wörterbuch. 2. verb. Aufl. Leiden: E. J. Brill.

Waitz, G. (ed.) 1964. Ex Saxonis Gestis Danorum. Monumenta Germaniae Historica. Scriptores 5, 29. Hannover 1892. Nachdruck. Stuttgart: Hiersemann \& New York: Kraus, p. 37-161.

Walde-Hofmann 1954 = Walde, A., Lateinisches etymologisches Wörterbuch. 3. neubearb. Aufl. von J. B. Hofmann. Bd. 2. Heidelberg: Carl Winter.

Walde-Pokorny $1930=$ Walde, Alois, Vergleichendes Wörterbuch der indogermanischen Sprachen. Julius Pokorny (Hrsg., Bearb.) 3 Bde. Berlin \& Leipzig: Walter de Gruyter.

Wieselgren, P. 1947. Namnet Reval. Meijerbergs Arkiv för Svensk Ordforskning. Del. 7, p. 88-116.

Wuttke, Heinrich (ed.) 1991. Aethici Istrici Cosmographiam ab Hieronymo ex Graeco in Latinum breviarium redactam. Nachdr. 2. Aufl., Leipzig 1854 (1853). Hildesheim, Zürich \& New York: Georg Olms. 